Revue de l'Institut des langues et cultures

d'Europe, Amérique, Afrique, Asie et Australie

$44 \mid 2021$

Peinture, identité nationale et style international en

Europe autour de 1900

\title{
Simbolismo e identidad nacional: Zuloaga y la pintura española en torno a 1900
}

Symbolisme et identité nationale: Zuloaga et la peinture espagnole autour de 1900

Symbolism and National Identity: Zuloaga and the Spanish Painting around 1900

\section{Alberto Castán Chocarro}

\section{(2) OpenEdition}

Journals

Edición electrónica

URL: https://journals.openedition.org/ilcea/12401

DOI: 10.4000/ilcea.12401

ISSN: 2101-0609

Editor

UGA Éditions/Université Grenoble Alpes

Edición impresa

ISBN: 978-2-37747-324-3

ISSN: 1639-6073

Referencia electrónica

Alberto Castán Chocarro, «Simbolismo e identidad nacional: Zuloaga y la pintura española en torno a 1900», ILCEA [En línea], 44 | 2021, Publicado el 02 noviembre 2021, consultado el 05 diciembre 2021. URL: http://journals.openedition.org/ilcea/12401 ; DOI: https://doi.org/10.4000/ilcea.12401

Este documento fue generado automáticamente el 4 diciembre 2021

(C) ILCEA 


\title{
Simbolismo e identidad nacional: Zuloaga y la pintura española en torno a 1900
}

Symbolisme et identité nationale : Zuloaga et la peinture espagnole autour de 1900

Symbolism and National Identity: Zuloaga and the Spanish Painting around 1900

\author{
Alberto Castán Chocarro
}

\section{NOTA DEL AUTOR}

Este artículo ha sido redactado en el marco del grupo de investigación de referencia Vestigium, financiado por el Gobierno de Aragón (H19_17R) y cofinanciado por el Programa Operativo Feder Aragón 2014-2020 «Construyendo Europa desde Aragón».

1 El 16 de enero de 1900 estallaba la polémica. La falta de espacio obligaba a una estricta selección en las obras artísticas que España iba a presentar en la Exposición Universal de París. El diario La Época citaba a los ya admitidos y cerraba la información con la auténtica noticia: «Ha producido un gran disgusto entre los pintores españoles el haberse rechazado un cuadro del pintor Zuloaga, obra muy hermosa a juicio de los que la han visto» (c., 1900: 1). La revista Pèl \& Ploma añadía otros nombres de excluidos y maltratados y, una semana después, recogía las opiniones publicadas en enero de ese año por Julius Meier-Graefe en L'Art Décoratif que situaban a Zuloaga en la estela de Goya y a la cabeza de la renovación del arte español. También afirmaba contar con una carta del pintor en la que les transmitía su satisfacción con el rechazo y su intención de no volver a participar nunca más en ninguna sección o exposición española («Ignacio...», 1900: s.p.). No se trataba de una reacción impulsiva, ya el 30 de diciembre de 1899, Zuloaga escribió a Isaac Albéniz planteando la posibilidad del rechazo e incluso su deseo de que así sucediera: «He enviado un cuadro grande a la exposición Universal, 
pero quizás me lo rechacen. ¡Ojalá!» (Zuloaga, 1899, citado en Lertxundi \& Novo, 2019: $56)^{1}$.

La obra en cuestión, Víspera de los toros (fig. 1), había recibido una primera medalla en la Cuarta Exposición General de Bellas Artes e Industrias Artísticas de Barcelona en 1898, donde fue adquirida por Santiago Rusiñol. Proscrita de la Universal parisina, Zuloaga la remitió a la séptima exposición de la Libre Esthétique de Bruselas. El éxito de crítica vino acompañado de su compra por parte del Estado belga para el Museo Real de Bruselas. Para Pèl \& Ploma, esto certificaba la incapacidad, el anti-patriotismo y la ligereza con que había actuado el comité español («Quadro...», 1900: s.p.).

Fig. 1. - Ignacio Zuloaga, Víspera de los toros (La veille de la course de taureaux), 1898. Royal Museums of Fine Arts of Belgium (Brussels), inv. nr. 3535, photo: J. Geleyns.

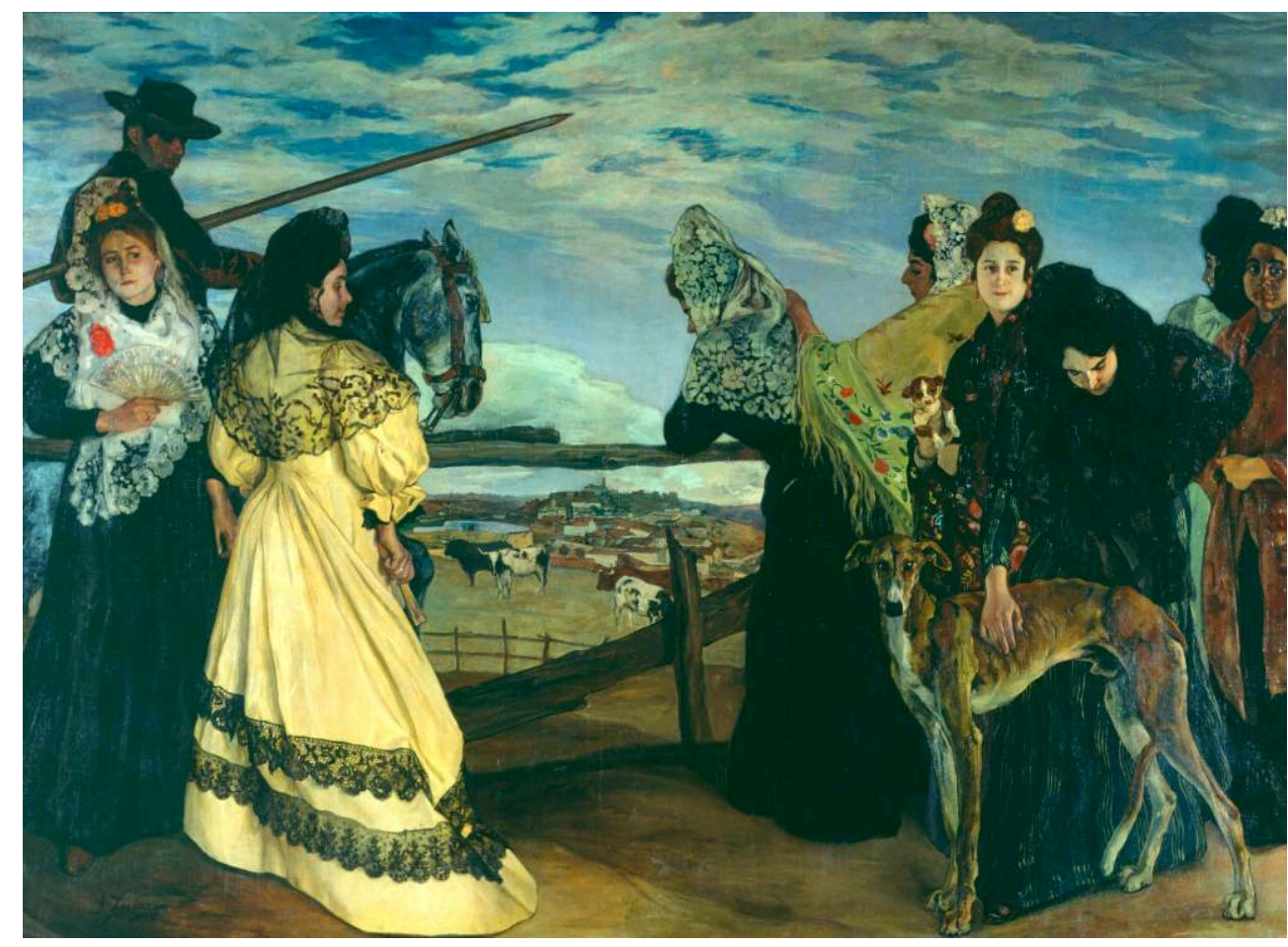

3 La prensa francesa también recogió lo sucedido. El semanario satírico Le Cri de Paris se dirigía de forma irónica a «notre ami» Zuloaga: «Nos félicitations! Sic itur ad astra», y hacía una interpretación política en clave nacionalista: «Mais il n'y aurait pas, entre l'artiste et son jury, que des dissentiments plastiques, il y en aurait de politiques. Ignatio Zuloaga est basque. Nationalisme en deçà des Pyrénées, nationalisme au-delà» (Le Cri de Paris, 1900: 3).

Aunque no parece que el origen vasco de Zuloaga motivara su exclusión, la afirmación da buena prueba de la importancia que el nacionalismo tenía en el debate político y cultural del momento y del modo en que esto se proyectó en la propia Exposición Universal (Stevens, 2000). Para entonces, la obra de Zuloaga era percibida por la crítica internacional como expresión de la «raza» y el carácter español, y como continuación de su escuela pictórica. Una visión que difundieron los medios españoles hasta que aparecieron las primeras voces críticas con la imagen del país que proyectaba. Una lectura atenta de las fuentes hemerográficas permite profundizar en la raíz de una controversia que, si bien trascendía el ámbito artístico, está estrechamente relacionada con la recepción y reformulación de una serie de novedades plásticas situadas entre el 
naturalismo y el simbolismo. La pintura de Zuloaga, alabada y rechazada desde presupuestos estéticos divergentes y pronto convertida en referente para la siguiente generación, es la expresión más clara de una de las cuestiones más repetidas entre los intelectuales del cambio de siglo: cuál era la verdadera esencia de lo español y de qué modo debía ser representado.

\section{Arte, nación e identidad en el fin de siglo}

En 1884, Manuel B. Cossío ya defendía una interpretación de la plástica como expresión del carácter nacional en Aproximación a la pintura española:

Pertenecen a la pintura española todas aquellas obras que lleven impreso el sello nacional, que muestren los rasgos distintivos y peculiares del genio del país [...]; que tengan, en suma, carácter. Por esto, la condición indispensable para dar carta de naturaleza de pintor español, no es la de haber nacido o pintado en España, sino la de mostrar en sus producciones el carácter patrio. (1985: 33)

6 Un carácter nacional que, como apuntó Portús (2012: 170), Cossío no llegó a definir más allá de una supuesta resistencia al influjo extranjero. Sus afirmaciones ejemplifican la importancia que las ideas de Hippolyte Taine tuvieron en la España del cambio de siglo: entre los miembros de la Institución Libre de Enseñanza -como el propio Cossío-, los ideólogos del regeneracionismo, los literatos del 98 o las principales voces del nacionalismo y el regionalismo, político y cultural. La obra de arte estaba determinada por la raza, el entorno y el momento, «por el conjunto resultante del estado general del espíritu y las costumbres ambientes» (Taine, 1960: 34). Un método de análisis histórico que, de acuerdo con Storm (2010: 8), determinados miembros de la siguiente generación de intelectuales europeos, como Langbehn, Barrès o Ganivet, convirtieron en categoría moral. Precisamente Ganivet proponía en Idearium español contrastar «el pensamiento filosófico de una obra de arte con el pensamiento de la nación en que tuvo lugar»:

Y cuanto más estrecha sea la concordancia el mérito de la obra será mayor, porque el artista saca sus fuerzas invisiblemente de la confusión de sus ideas con las ideas de su territorio, obrando como un reflector en el que estas ideas se cruzan y se mezclan, y adquieren al cruzarse y mezclarse la luz de que separadas carecían. (1897: 135)

El arte español, tanto del pasado como del presente, solo podía aspirar a ser expresión de esa concordancia, a dar cuenta de la identidad de una nación, de un pueblo.

«Paso libre, paso al Norte!», exclamaba Josep María Roviralta desde las páginas de la revista Luz tras certificar la degeneración de una «raza» -la española- en decadencia: «que vengan ahora otras y que nos enseñen lo que nosotros no podemos ni saber ni muchas veces llegar a comprender» (J. M. ${ }^{\mathrm{a}}$ Roviralta, 1898: 62-63). Menos derrotista era la actitud de Macías Picavea, que encontraba en el regionalismo uno de los remedios que podían servir al país para salir de la crisis en que se encontraba inmerso. Un regionalismo respetuoso con una unidad nacional que se asentada en las peculiaridades de sus diferentes pueblos: «el triunfo de la variedad que, por serlo, lo será también de la unidad» (Macías, 1899: 461). Un movimiento en el que artistas y literatos estaban a cargo de una fase de «preparación espiritual» -según expresaba el Manifiesto para la Solidaridad Gallega (1907)-, imprescindible para «conquistar la opinión y la mentalidad del pueblo», de acuerdo con lo apuntado algo después por el francés Jean Charles-Brun (1918: 189). De ese modo, el contexto español dio lugar a un poderoso imaginario 
regional que fue promovido "tanto por "españolistas regionales" como por “regionalistas españoles"» (Núñez, 2006: 309), en el que la pintura desempeñó un papel clave como expresión, en última instancia, del nacionalismo cultural que en ese mismo momento proliferaba en toda Europa (Thiesse: 1999; Hutchinson: 2013).

\section{Zuloaga y la pintura francesa: una solución plástica al problema identitario}

Tras instalarse en París entre 1889 y 1890, anota Lertxundi (2019: 22), Zuloaga pasó cuatro años en los que se acercó a naturalistas, impresionistas y simbolistas, tres ingredientes clave de su lenguaje definitivo. Y que, en buena medida a través de este, lo fueron también en la pintura desarrollada en España a partir de 1900. El regionalismo plástico español, por más que se quisiera expresión de lo castizo y encontrara sus referentes en la tradición de la escuela española, tiene una raigambre francesa. Juan de la Encina lo vio claro al tratar de definir el arte vasco: «En la Villa de todos los fermentos hallaron también los artistas vascos, fresco y renovado, el fermento de su arte nacional: en ella recibieron la primera iniciación eficaz en el sentido de su genuina tradición» (Encina, 1919: 8). Para comprobarlo, basta comparar El viejo músico [1862] (fig. 2), de Manet -con todas las deudas que presenta con la escuela española-, con Vísperas de los toros (1898), Mi tío y mis primas (1898) o El alcalde Torquemada (1903), de Zuloaga.

Fig. 2. - Édouard Manet, El viejo músico, 1862. Courtesy National Gallery of Art, Washington.

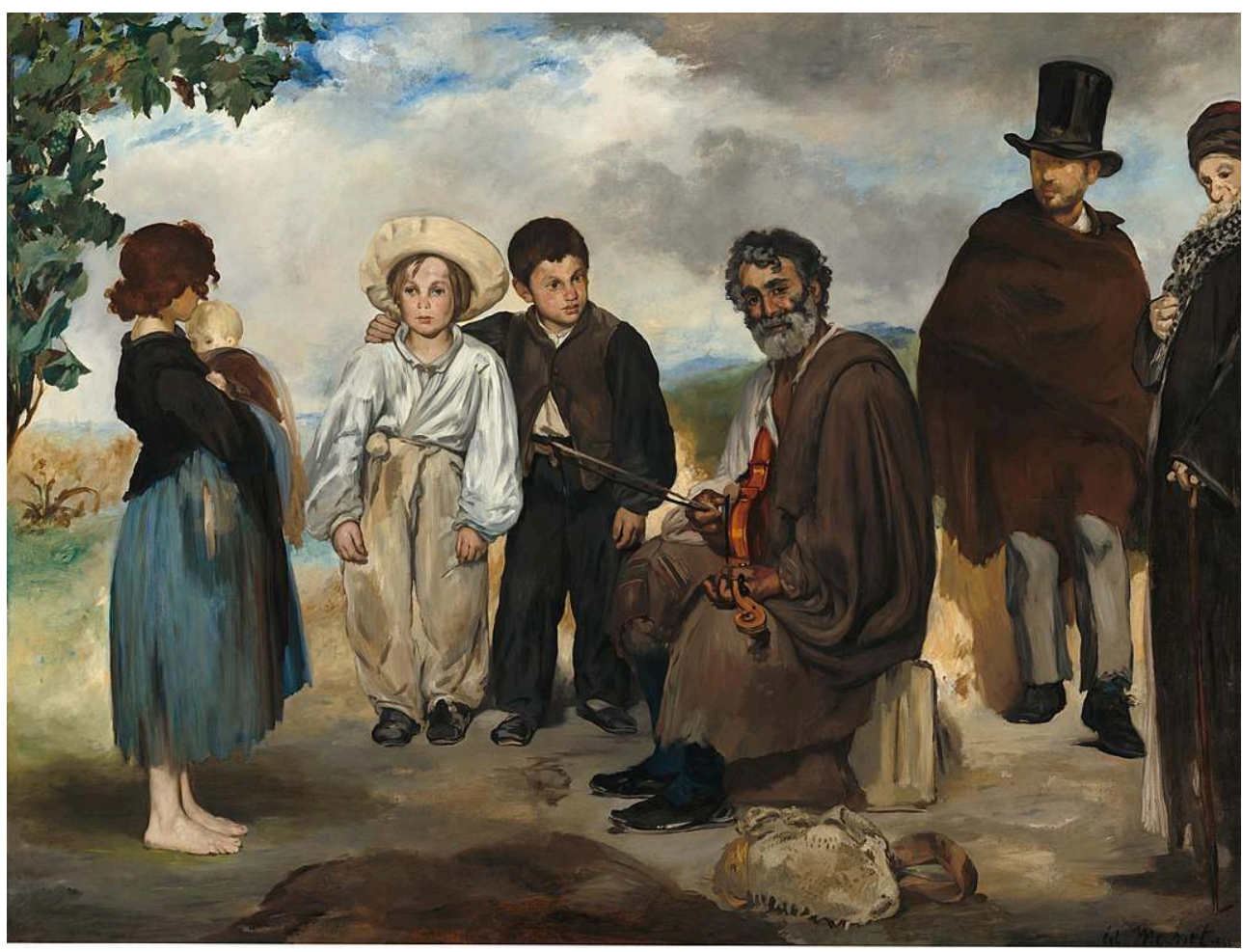

En las primeras obras parisinas de Zuloaga, imágenes de vagabundos por las calles de la ciudad, se impuso un realismo en la línea de Raffaëlli. Precisamente este, con La familia de John el Cojo, campesinos de Plougasnou [1876] (fig. 3), presentada en el Salón de 1877 y 
expuesta de nuevo en la Universal de 1889, anunció una serie de fórmulas que definirían el regionalismo plástico. Incluso algunas que se suelen relacionar con la influencia simbolista, como el quietismo, la frontalidad o la falta de comunicación entre los personajes. Todas presentes en Zuloaga desde finales de siglo.

Fig. 3. - Jean-François Raffaëlli, La familia de John el Cojo, campesinos de Plougasnou, 1876. Musée d'Orsay, Paris.

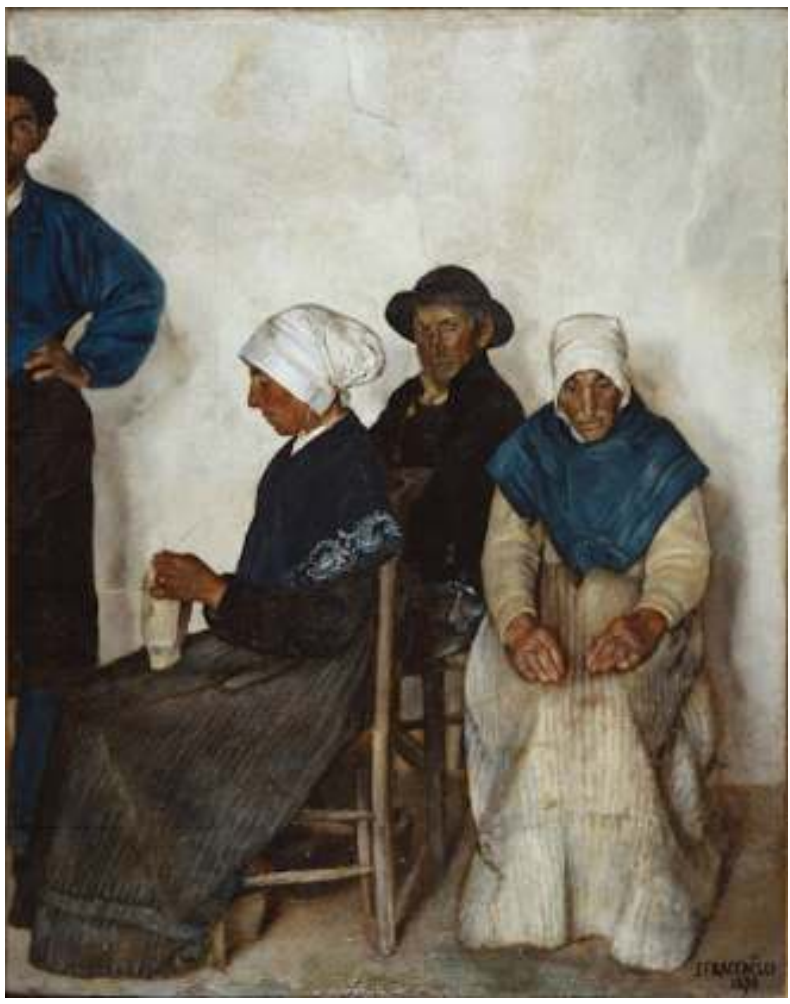

(c) Musée d'Orsay, Dist. RMN-Grand Palais / Patrice Schmidt.

11 Richard Thomson (2012) ha definido el naturalismo como el lenguaje dominante en el contexto francés de las dos últimas décadas del siglo XIX, acorde con los intereses de la Tercera República y expresión, entre otras cuestiones, de sus inquietudes en torno a la identidad nacional. Entendido como un lenguaje versátil que admitía una interminable variedad de soluciones, Thomson llama la atención sobre los cambios que experimentó en la década de 1890, cuando abandonó la impresión de inmediatez de los primeros años para optar por una «slightly more stylised, even ritualistic kind of composition» (2012: 135-136). En esos mismos años, prosigue, Maurice Le Blond defendía en Essai sur le naturisme (1896) un nuevo consenso literario, atento al devenir de las artes plásticas, que trataba de fusionar lo mejor del naturalismo y el simbolismo. Aunque Thomson no termina de apuntar en esta dirección, cabría trazar una equivalencia entre el ámbito literario y el pictórico que explique el modo significativamente diferente en que comenzaron a representarse escenas aparentemente tomadas del natural, pero que cada vez remitían de forma menos directa a este. La reacción simbolista iniciada pocos años antes no pudo dejar indiferentes a los naturalistas. Precisamente fue naturisme la etiqueta que utilizó Raymond Bouyer para referirse a las obras presentadas por René Ménard, Lucien Simon, Charles Cottet, Dauchez y Ulmann en el Salón de la Sociedad Nacional de Bellas Artes de 1898. Encontraba que estos encarnaban «l'équilibre entre les forces opposées, -ni bizarrement mystique, ni lourdement documentaire-, pouvant personnifier 
l'idéal en face des hasards poudreux de l'impression, sachant venger la nature en regard des géométries puériles du symbole» (1898: 119). Noción en la que insiste ante el Triptyque des Adieux (1898) de Cottet (fig. 4): «Ni symbole immatériel, ni document inutile». Zuloaga, amigo de Cottet y presente en ese mismo Salón, ejemplificaría esa misma evolución desde los postulados del naturalismo hacia una nueva visión de la realidad acorde con determinadas fórmulas simbolistas.

Fig. 4. - Charles Cottet, Triptyque des Adieux (Au pays de la mer : Ceux qui s'en vont, Le repas d'adieu, Celles qui restent), 1898. Musée d'Orsay, Paris.

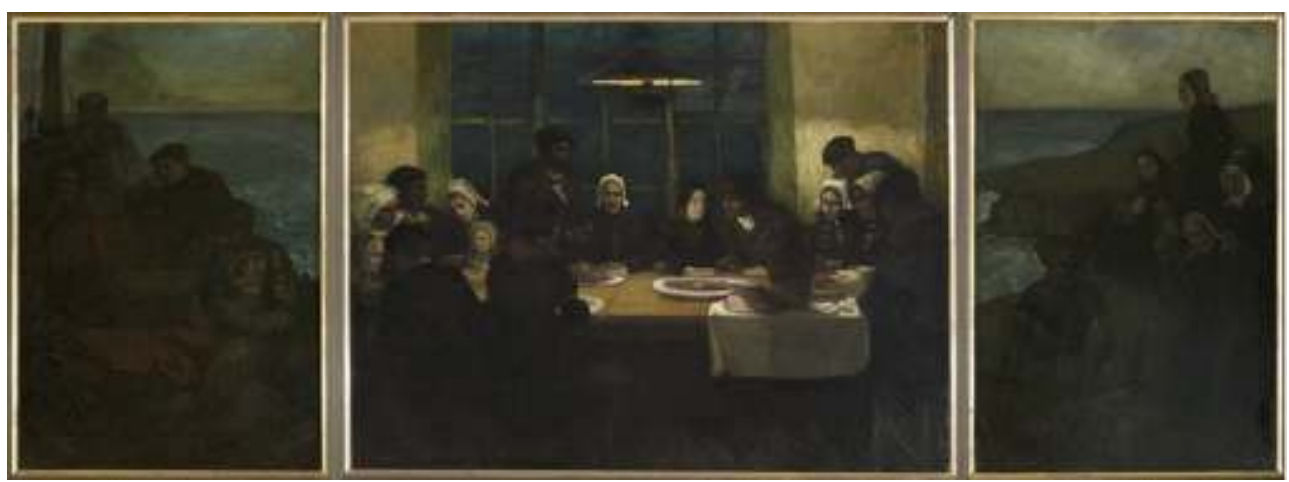

(c) Musée d'Orsay, Dist. RMN-Grand Palais / Patrice Schmidt.

En realidad, ni siquiera el simbolismo más estricto resultaba ajeno a las preocupaciones identitarias del fin de siglo. Michelle Facos (2009) se ha referido a la efectividad del simbolismo para promover la identidad nacional. Sus imágenes, añade, podían encerrar mensajes polivalentes, capaces de comunicarse con diferentes tipos de audiencias: la foránea, la nacional y la regional. En 1896, Albert Trachsel, poeta y artista suizo, trató de establecer una alianza entre el simbolismo y el nacionalismo a través de su tratado Réflexions à propos de l'art suisse à l'Exposition nationale, en el que exhortaba a los artistas suizos a crear un arte que respondiera a las características de su propia nación. Unas ideas que, según Hirsh, contribuyeron a transformar la plástica de su íntimo amigo Ferdinand Hodler, que para esa misma exposición realizó veintiséis paneles decorativos con figuras que representaban los cantones suizos. En esas fechas, Hodler se adentraba en una nueva etapa caracterizada por "optimistic images of strength and spirit», de acuerdo con la voluntad de formular un estilo propiamente suizo (Hirsch, 1994: 95).

Tras participar en las exposiciones de impresionistas y simbolistas celebradas en Le Barc de Boutteville, Zuloaga presentó en el Salón de la Sociedad Nacional de $1894 \mathrm{Le}$ nain d'Eibar [1893-1894] (fig. 5), su primer tipo rural ante un paisaje con una composición que se inscribía en la tradición del retrato español barroco. Esta fue la vía que explotó en lo sucesivo, siendo clave su traslado a Sevilla en otoño de ese año ${ }^{2}$. 
Fig. 5. - Ignacio Zuloaga, El enano don Pedro (Le nain d'Eibar), 1893-1894. Legs Van Cutsem - 1904, Tournai, Musée des Beaux-Arts.

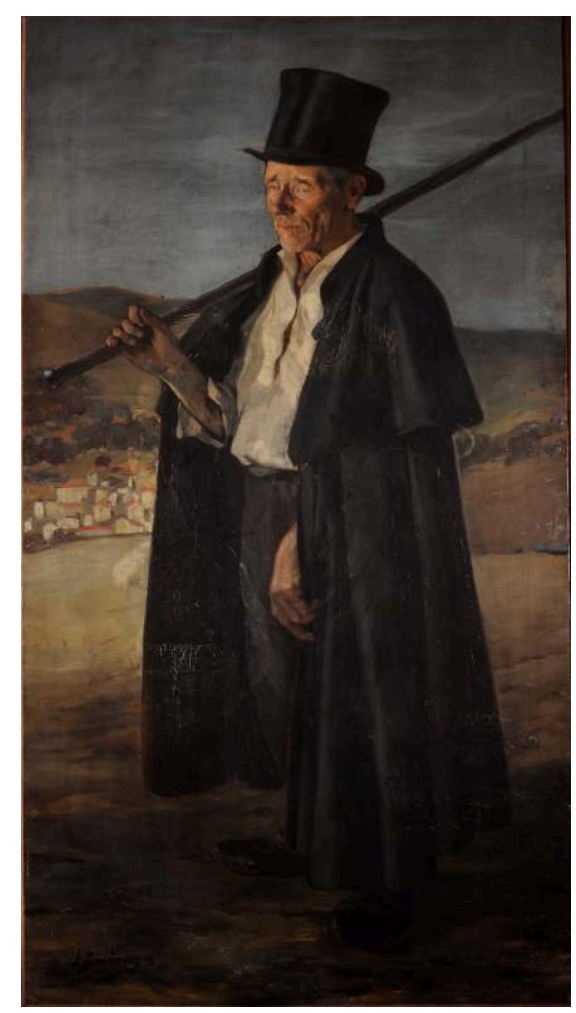

Desde que salí de París, mi [vida] es la de un verdadero gitano. Me vuelvo salvaje, o mejor dicho, lo soy; me olvido de París y de su refinadas teorías y me hago español, español de verdad, y procuro pintar en español y pintar España (país bien hermoso) [Zuloaga, 1896, citado en Ybarra, 2017: 271] $]^{3}$.

14 Así describía a Maxime Dethomas la experiencia sevillana emprendida apenas dos años antes. Se trataba de una retirada hacia el origen, hacia lo primitivo, no muy distinta de la que autores franceses cuya obra admiraba y con los que mantenía relación y/o había expuesto -Gauguin, Bernard, Cottet...-, habían realizado en Bretaña. Buscó el equivalente hispano de aquellos tipos que había visto representar a simbolistas y naturalistas franceses y en su búsqueda se decidió por conectar con lo auténticamente español o, al menos, con lo que se entendía como tal. Zuloaga conocía los gustos e intereses del contexto parisino, donde buscaba triunfar, por lo que el traslado a Andalucía tuvo que ser una decisión meditada. Mostró sus primeros resultados en una exposición celebrada en Le Barc de Boutteville en 1895, titulada Espagne blanche. La estrategia funcionó. Al menos si atendemos a la buena reacción de críticos como el simbolista Charles Morice, que entendió el camino seguido por el pintor: partir de la tradición de los grandes maestros, especialmente El Greco - «mal comprise, même en Espagne»-, para representar una nación llena de contrastes, no solo blanca, sino también negra:

D'un talent, donc, très traditionnel, d'un tempérament très national, il a compris les ressources que garde aux peintres cette Espagne aux contrastes violents, [...] avec le mélange d'une des civilisations les plus raffinées qui furent jamais et de la barbarie invincible qui ajoute la grâce sauvage et pittoresque de la vie [...]. Espagne Noire, Espagne Blanche, et cette étrangement belle tribu nomade des Gitanes qui se retranchent dans leur langue et dans leurs usages incommunicables : voilà le thème de l'œuvre à laquelle Zuloaga se dédie. (1895: 180) 

como representación de las esencias nacionales por parte de la crítica internacional se inició entonces y se mantuvo en lo sucesivo. Paralelamente, Zuloaga llevó a cabo un proceso de depuración y alejamiento de la anécdota en el que la vía simbolista resultó definitiva. "Sufrió una evolución introspectiva para explorar las emociones y los estados de ánimo, y generar sensaciones de inquietud en el espectador», escribe Lertxundi (2019: 41). Alfredo Opisso expresaba su desconcierto al ver las obras que el artista presentó en la Tercera Exposición General de Bellas Artes de Barcelona: «A la derecha hay un árbol simbólico; a la izquierda un río simbólico, que hace eses entre montañas simbólicas. ¿Qué hacen ese picador y esa mujerzuela fea [...]? ¡Misterio, para mí!» (Opisso, 1896: 410). coincidido en las exposiciones de Le Barc de Boutteville, Bernard no le recodaba (Vian, 2017: 61 y 63). Había llegado a España procedente de Egipto, donde residía desde 1893. En Granada, según narró por carta a su padre, sufrió una intoxicación accidental con monóxido de carbono en la que tuvo una visión de su propia muerte rodeado de pinturas de los maestros venecianos que sintió como una revelación (Bernard, 1899, citado en Leeman, 2014: 21). Pronto se trasladó a Sevilla, y allí pudo conocer la obra de los españoles: Zurbarán, Murillo y Valdés Leal, «qui me firent ouvrir les yeux sur la plastique définitive» (Bernard, 1905, citado en Leeman, 2014: 21). Después pudo ver a El Greco y Velázquez en una visita al Prado realizada junto a Zuloaga, quien consideró que gracias a su paso por España, su obra se había vuelto «plus coloriste, plus sobre, plus sincère, plus peintre» (Zuloaga, 1898, citado en Plessier, 1995: 19). Habían iniciado una amistad asentada en un mismo ideal: renovar la plástica desde una relectura de la tradición.

En Sevilla, Bernard pintó obras como Baile de gitanos (1897) o Mendigos españoles (1897) (fig. 6), temprana expresión de las posibilidades que ofrecía la fusión del simbolismo finisecular con el naturalismo hispánico. Figuras expresivas al tiempo que hieráticas, incomunicadas entre sí y ajenas a su escenario, que en ocasiones observan inquisitorias al público. De acuerdo con Leeman, Bernard somete sus motivos de inspiración a un sutil proceso de estilización «destiné à produire des formes générales, affranchies de la sphère de l'anecdote pour se hausser à celle de la représentation de la condition humaine» (2013: 263). Una interpretación de la realidad descarnada, fría, distante. La misma vía por la que se estaba adentrando Zuloaga, como evidencian los rostros de las dos protagonistas de $\mathrm{Mi}$ tío y mis primas [1898] (fig. 7). La influencia fue mutua. Algo evidente si comparamos el retrato de Bernard pintado por Zuloaga hacia 1897 con los dos autorretratos que el primero realizó ese mismo año. O si observamos Vísperas de los toros (1898), Lola, la gitana (1901), Gallito y su familia (1903) o La calle de las pasiones (1904), de Zuloaga, a la luz de las escenas andaluzas del francés. 
Fig. 6. - Émile Bernard, Mendigos españoles, 1897. Colección particular.

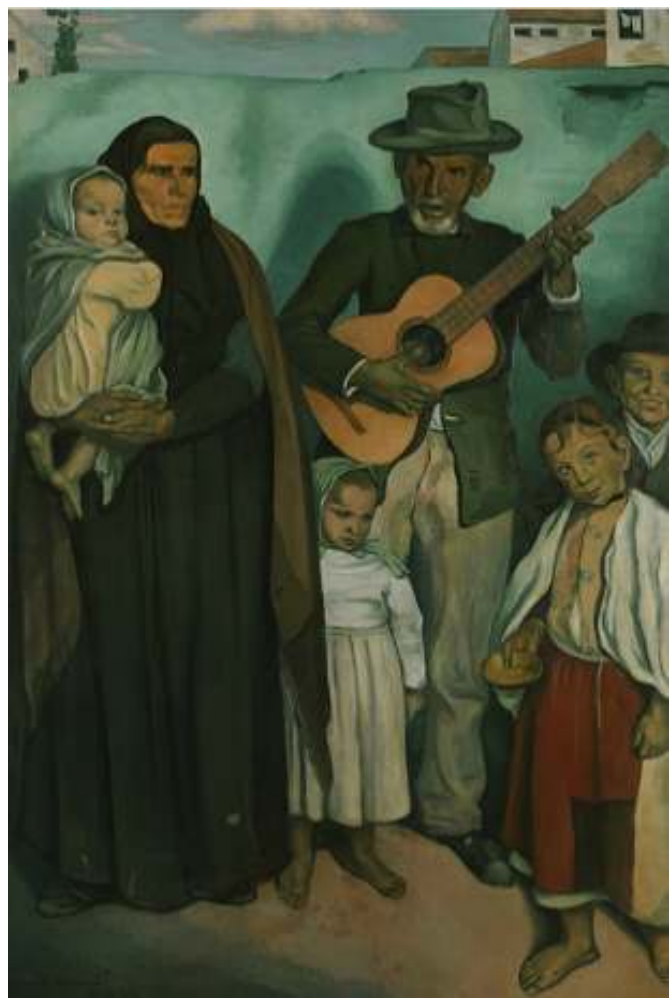

Fig. 7. - Ignacio Zuloaga, Mi tío y mis primas, 1898. Musée d’Orsay, Paris.

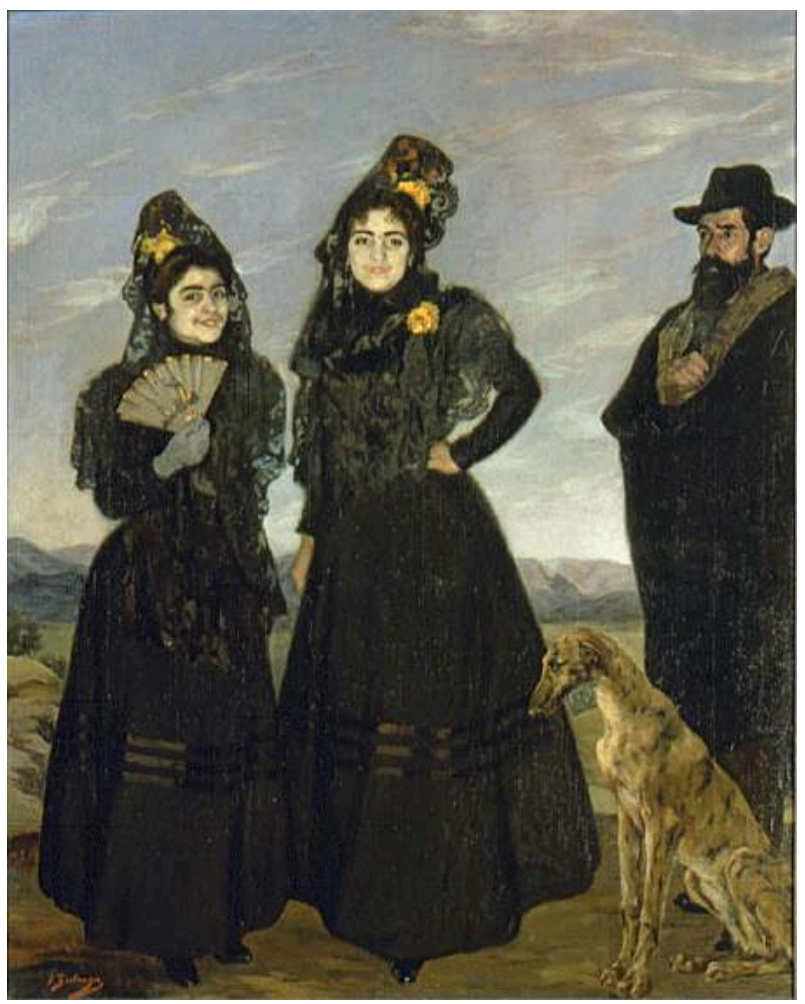

(c) Musée d'Orsay, Dist. RMN-Grand Palais / Hervé Lewandowski. 
En 1898 Zuloaga descubrió Segovia y comenzó a representar sus tipos. Menos condicionados por la carga del tópico, del folclore y la fiesta, facilitaron una interpretación más cruda y sobria de la realidad. Aunque no abandonó de forma inmediata la temática andaluza, inició entonces su rumbo definitivo: Castilla sería su España.

\section{La pintura española en la Exposición Universal de 1900}

19 Una vez inaugurada la exposición de París y vista la sección española, se reabrió la polémica en torno a la exclusión de Zuloaga. El 1 de mayo, el diario La Época hacía una breve crónica que apuntaba cierta decepción: «en general, la sección española de Bellas Artes es notable; pero no ha llenado todas las esperanzas» («La Exposición...», 1900: 2). Y recordaba «la injusticia cometida» al rechazar a Santiago Rusiñol -que sí participaba - y Zuloaga. Pocos días después, Heraldo de Madrid publicaba una carta en la que el pintor Luis Jiménez felicitaba a aquellos artistas que no habían enviado sus obras por haberse ahorrado «el ridículo de una instalación deplorable» (1900: 1). Una queja que se hizo recurrente y que Ulpiano Checa completó con un ataque a todo el proceso de selección. Fue la sección parisina del jurado la que rechazó a Zuloaga, «que tiene una de sus obras en el Museo de Luxemburgo», por lo que no es extraño "que el resultado final sea tan tristísimo» (1900: 1). Juan B. Enseñat escribía en La Ilustración Artística: «Mucho se ha comentado en el mundo artístico la expulsión de las pinturas de Zuloaga, sin que nadie haya encontrado motivo plausible [...]. El Sr. Zuloaga es considerado como un verdadero artista, genuinamente español, dentro de la escuela de pintura vigorosa y sobria de nuestros grandes maestros» (1900: 490).

Aunque la denuncia más contundente llegó casi un año después, tras el éxito del pintor en el Salón de 1901. "¡Qué lo ahorquen!», titulaba Louis Bonafoux una columna en la que pedía la ejecución del jurado bajo la obra de Zuloaga: «que dicho Jurado gustase o dejase de gustar del realismo de Zuloaga, eso no le autorizaba de ningún modo a desechar las obras de un artista calificado de maitre por las Prensa y la crítica de París»; y más teniendo en cuenta que había seleccionado «cuadros malos, feísimos, horrorosos», "pintados con brocha gorda y aceite de bellotas» (1901: 1). Recordaba también Bonafoux el daño que la decisión generó en un Zuloaga «furibundo», que se declaró resuelto «a naturalizarse extranjero».

21 Tampoco la crítica francesa hizo concesiones a la participación española. «L'Espagne ne nous fournit pas un spectacle tout à fait aussi réconfortant», escribía Léonce Bénédite (1900: 589). Para a continuación aludir a cómo «l'esprit de l'Inquisition» había reaparecido en la actuación del comité: «Je n'ai pas besoin de nommer M. Ignacio Zuloaga, dont l'exclusion a fait scandale. L'exposition, au Luxembourg, des portraits de femme de cet artiste, qui a renoué le fil rompu de la vraie tradition locale, a essayé, du moins, de réparer pour le public cet impardonnable oubli». En esa misma línea insistió en los Rapports du Jury International, donde los comentarios sobre la participación española aparecían ilustrados, únicamente, por dos pinturas del ausente Zuloaga.

Su exclusión de la Universal de 1900, junto con el éxito que tenía en Francia, Bélgica o Alemania, cimentó la percepción de Zuloaga como un pintor que, pese a triunfar en el extranjero, era maltratado en su propio país. Desde entonces un lugar común 
subrayado en cualquier crónica que se le dedicara. En realidad, las menciones aparecidas en la prensa española hacia 1900 eran más bien reflejo de los comentarios elogiosos que se le dedicaban en otros países: era un artista representativo de lo español y heredero de la tradición pictórica. Ajeno por completo al medio artístico madrileño, tan solo en el País Vasco y Barcelona habían podido conocer directamente sus obras. En noviembre de 1900, Julio L. Carrión recogía en la revista Iris los comentarios del belga Octave Maus, para el que las figuras de Zuloaga mostraban «el carácter esencial de la nación más claramente que muchos cuadros que recuerdan la convencional España de zarzuela» (1900: s.p). Mientras que el año siguiente Ricardo Blasco definía Paseo después de la corrida de toros como «una nota muy española en la que se junta la buena cepa de los grandes maestros españoles, con ese espíritu moderno y personal que pone el sello de Zuloaga» (1901: 1).

\section{España real / España ficticia}

El cuestionamiento de la imagen de España que ofrecía Zuloaga por una parte del medio artístico español llegó un poco después, hacia 1903 (Lertxundi \& Novo, 2019: 63). Uno de los primeros fue Pérez Jorba desde La Revista Blanca, señalando que, en busca del éxito, Zuloaga «había querido adaptarse al gusto parisién», haciendo de una de las manolas de Preparativos para la corrida (1902) «una española traducida al francés» (1903: 732). Y no andaba desencaminado. Incluso en un artículo dedicado a desgranar los triunfos de Zuloaga como el que le dedicó Ramiro de Maeztu en La Lectura, se dejaba entrever esa misma crítica: «A las veces, la España que refleja en sus cuadros más se acerca a la soñada por los extranjeros que a la que nos muestra la vida cotidiana» (1903: 22). El año siguiente, al ocuparse de la Exposición Nacional, José Francés aludía a los imitadores de Zuloaga recordando que este falseaba España "presentando la que en París gusta... y pagan» (1904: s.p.).

La crítica por adecuarse al gusto francés era un lugar común que enmascaraba la resistencia a cualquier novedad en materia artística, al tiempo que ponía en evidencia la importancia del discurso nacionalista en el análisis plástico. El problema con Zuloaga residía, además, en si la España que retrataba era real o no y, en consecuencia, qué imagen del país proyectaba. Para la crítica extranjera, la España de Zuloaga era la España real. Sergéi Diághilev lo tuvo claro tras ver el Salón de 1901: «una España auténtica se nos ha aparecido con los cuadros de Zuloaga» (citado en Ybarra, 2017: 257). No se trataba de la España tópica, sino de una «España triste, sucia e impresentable, con las fisonomías pintarrajeadas de sus prostitutas y las jetas canallescas de sus hombres embozados en capas». Una idea que se mantuvo en los relevantes artículos que la prensa dedicó al pintor en 1903; el mismo año en que se le cuestionaba desde España. Arsène Alexandre afirmaba en Le Figaro que sus pinturas eran "veraces», «naturales», alejadas de las «espagnoleries criardes» (1903: 3); mientras que Henri Frantz anotaba en The Studio: «he remains true to the absolute reality, to the sheer impression of the things he has seen» (1903: 165).

Solo los miembros de una nueva generación de intelectuales españoles se sentían cómodos con esa visión de España. «Es realista y considera que no cabe enmendar la plana a la naturaleza» (1903: 263), afirmaba Valenzuela la Rosa en un artículo que tituló «El caso Zuloaga». Fue uno de los primeros en salir en su defensa - «es español por su nacimiento y sus producciones»-, lo que Zuloaga le agradeció por carta: «Es usted el 
primero en España que se ha atrevido a romper el silencio que me aislaba y no puedo menos de agradecer esa buena acción» («De arte...», 1904:1).

El debate alcanzó su punto álgido en 1910 bajo la denominación de «cuestión Zuloaga». Francisco Alcántara definía el problema: «existe aquí en crítica de arte una cuestión Zuloaga por resolver, una cuestión interior, de fronteras para adentro, y no puede resolverse sin destruir antes lo que ha impedido hasta hoy el contacto del espíritu nacional con la obra del gran pintor» (1910: 2). Y mientras que Azorín entendía que bastaba un vistazo "para comprobar que el país que retrata el Sr. Zuloaga no es la España real y auténtica en que todos los españoles vivimos» (1910: 6), Maeztu, iniciador de la polémica, afirmaba justo lo contrario. Ortega y Gasset vio sus cuadros como «ejercicios espirituales que nos empujan, más que nos llevan a un examen de conciencia nacional» (1910a: 1), además de considerar que la pregunta a la que arrastraban: «¿Es así España o no es así?» (1910b: 1), evitaba que se hablara de pintura. Maeztu trató de zanjar el asunto: «Ojos de Europa y corazón de España; no es otro el secreto de Ignacio Zuloaga. [...] ¿no hay en ese secreto la única fórmula posible de un arte nacional actual y europeo?» (1910: 1). Incluso Azorín terminó por reconocer que en su pintura «hay mucho de verdad» (1912: 1).

El propio Zuloaga quiso subrayar entonces su firme alejamiento del realismo más estricto:

¡No y mil veces no! No quiero copiar la Naturaleza tal como es. Para eso se han inventado las máquinas fotográficas [...]. Busco el alma a través de un realista soñador. Busco la línea, el arabesco, la armonía, la visión personal y la simplificación. Busco la fuerza del atrevimiento, la franqueza de las ideas, el gritar fuerte y profundo, el sintetizar el alma castellana, el sacrificar muchas cosas para hacer valer una esencial (Pujol, 1912: 1).

Si para la historiografía actual los vínculos de Zuloaga con la poética simbolista resultan evidentes ${ }^{4}$, no lo fue tanto para sus contemporáneos. Bénédite recordó en su monografía sobre el autor su paso por los círculos neoimpresionistas y simbolistas, en la «bonne compagnie» (1912: 21) de Gauguin, Signac, Bernard, Denis y, por supuesto, Cottet; además de indicar que su realismo era interpretativo y sintético. Por más que fuera realista, continuaba, «n'est pas un naturaliste» (1912: 66). Poco a poco se entendía que solo desde una interpretación subjetiva de la realidad podía cumplir con su intento de representar el «alma castellana». «Gregorio el Botero es un símbolo; si se quiere, un mito español. Y en esto consiste la fuerza de Zuloaga: en ser un creador de mitos», escribía Ortega y Gasset (1911: 3). El padre M. Gil, autor de uno de los ensayos reunidos por The Hispanic Society of America con motivo de la exposición que le dedicó en 1909, encontraba en Tipo de Segovia [1906] (fig. 8) un carácter estereotipado, «más que a un psicólogo a un técnico» (1909: 96), en contraste con Los flagelantes (1908), donde sí sintió la presencia de «una de las fases del alma española [...] la que mejor sintetiza la contextura espiritual de nuestra raza». Frente al naturalismo más sobrio, era en el simbolismo más crudo y artificioso donde encontraba la auténtica valía del autor. En su opinión, todo en Zuloaga quedaba supeditado a un ideal, nunca copiaba, de modo que personajes, objetos y paisajes «tienen una trascendencia más grande de la que tienen en la realidad [...]; necesitamos penetrar en el fondo, en la entraña, en la contextura psicológica de estos pueblos, de estos individuos representativos de nuestra raza» (112). Ahí, remataba, es donde reside la «psicología peculiar» de España. 
Fig. 8. - Ignacio Zuloaga, Tipo de Segovia, 1906. Museo Nacional Centro de Arte Reina Sofía, Madrid.

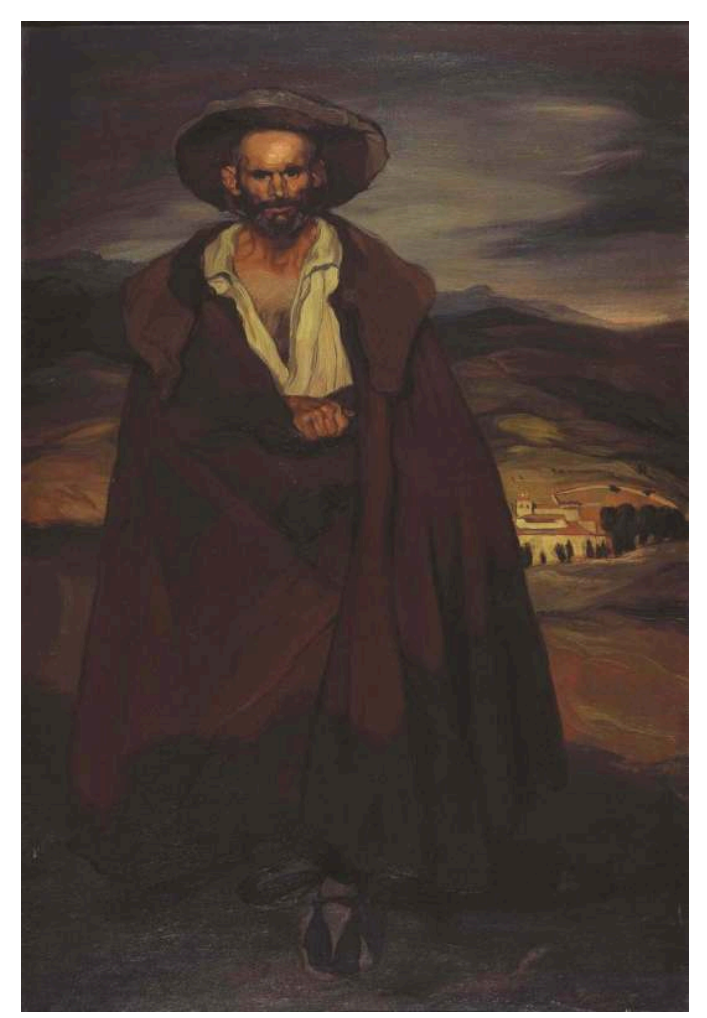

(ㄷ) Archivo Fotográfico Museo Nacional Centro de Arte Reina Sofía.

\section{Sorolla y la vía naturalista}

Si el naturalismo francés fue capaz de encarnar los ideales de la nación propugnados por la Tercera República, no sucedió así con el español, dividido entre un realismo social que abrazaba en ocasiones un tono abiertamente melodramático y un costumbrismo de herencia romántica cuya representación de tipos y paisajes perpetuaba una visión tópica y dulcificada de lo rural. En 1895, Unamuno subrayaba la necesidad de trascender este ámbito: «El arte por fuerza ha de ser más castizo que la ciencia, pero hay un arte eterno y universal, un arte clásico, un arte sobrio en color local y temporal, un arte que sobrevivirá al olvido de los costumbristas todos» (1895: 29).

La recepción de la obra de Sorolla, percibido como principal representante del naturalismo español, resultó mucho menos problemática que la de Zuloaga. El crítico Saint-Aubin señalaba en 1899 lo singular de su caso: «ante los cuadros de Sorolla nadie discute» (1899: 1). La crítica alababa su capacidad para representar la realidad, su novedoso tratamiento de la luz solar y del color o, en general, su habilidad técnica; también destacaba su modernidad al tiempo que su ascendencia velazqueña, y por tanto española. Tan solo voces puntuales como la de Francisco Alcántara lo cuestionaron. En 1901 planteó «La cuestión Sorolla» -nótese la coincidencia terminológica- para concluir que en su obra y magisterio se resumían «los defectos de nuestro arte», abocado a un "naturalismo fugaz» que derivaba en una pintura superficial y falta de reflexión (1901: 832). Algo antes, Luis M. Cabello había puesto en duda la «nacionalidad» de su pintura: «Ese naturalismo español del que a Sorolla se le 
supone campeón, no conserva rastros ningunos de la nacionalidad que se le supone», afirmaba (1897: 164). De hecho, por más que se subrayara su querencia por las playas levantinas y los tipos de «su tierra», no se encontraba en ninguno de estos aspectos la encarnación de un alma o una raza, ni valenciana, ni española (fig. 9). Pese a que el debate en torno a las relaciones entre arte y nación (o región) estaba abierto, no parece que la pintura de Sorolla lo encarnara. Es más, era una cuestión completamente ajena a los intereses del autor. Frente a lo que sucedería más adelante, Blasco Ibáñez fue uno de los pocos que, en 1900, encontraba en su obra «la personificación del pueblo valenciano» (1900: 1). En cualquier caso, los triunfos de Sorolla eran los triunfos del arte nacional. Como sucedió con el Grand Prix obtenido en la Universal de 1900.

Fig. 9. - Joaquín Sorolla, Cosiendo la vela, 1896. Ca' Pesaro Galleria Internazionale d'Arte Moderna.

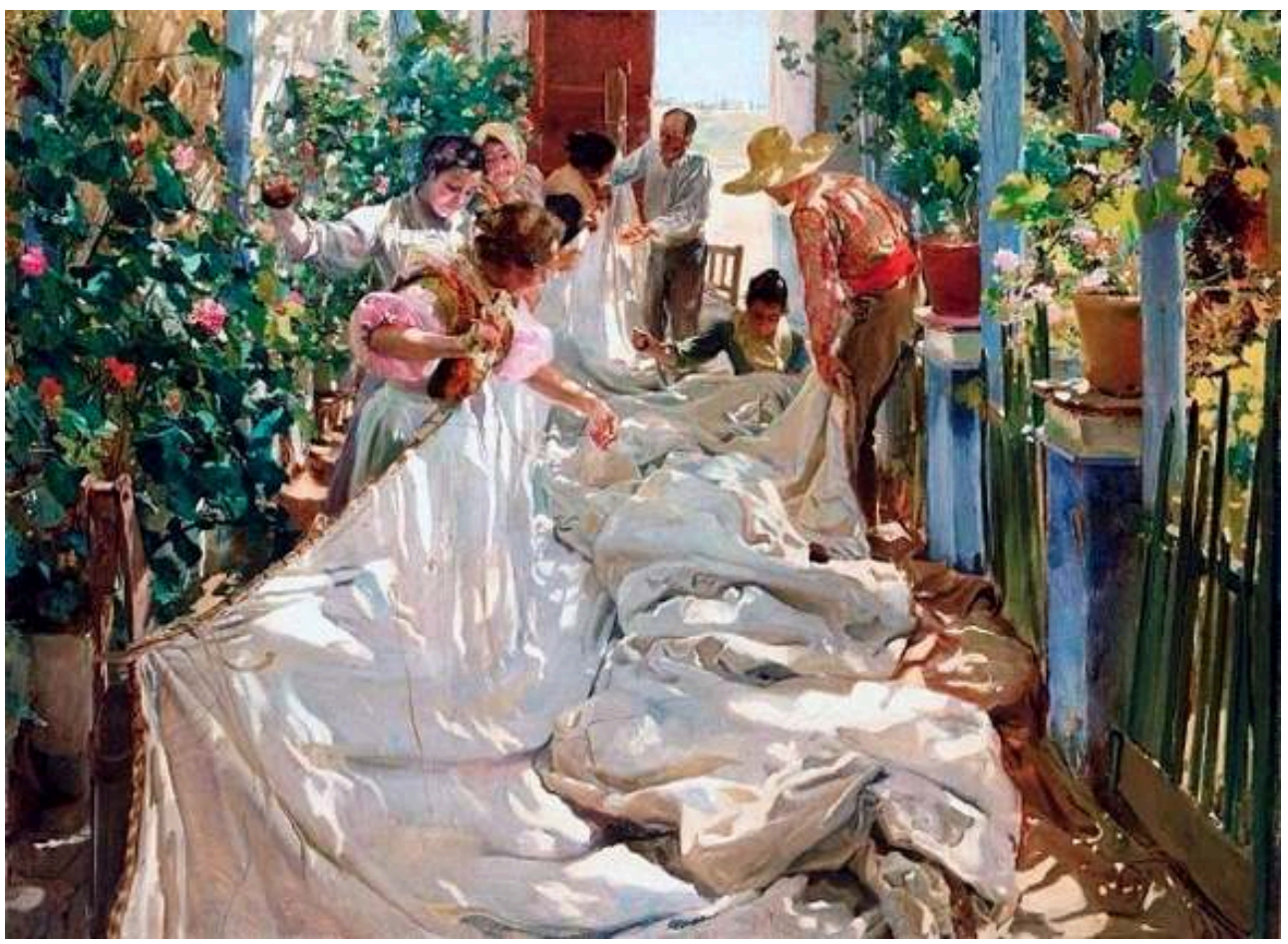

(c) Archivio Fotografico - Fondazione Musei Civici di Venezia.

31 Tampoco la crítica internacional vio en sus escenas valencianas una encarnación de lo español, sino más bien un desarrollo del impresionismo y el naturalismo francés. "Se rattachant au développement de l'école française vers les recherches naturalistes, M. Sorolla y Bastida raconte la blancheur des voiles gonflées dans la fraicheur du matin et le papillotage joyeux de la lumière sous les treilles fleuries», escribía Bénédite (1904: 670-671). El propio Sorolla evitaba conscientemente el tratamiento de lo que podían considerarse «escenas españolas», tal y como relataba a Leonard Williams en un artículo para The Studio traducido en diferentes medios españoles: «¿Qué quieren, dice amargamente, voy a pintar un señor español con sombrero ancho y polainas, o una duquesa colgada del cuello de un torero? Yo aseguro que no hago más que pintar mi país como es y a mis paisanos como son» (1904: 125).

32 Aureliano de Beruete, que en Historia de la pintura del siglo XIX (1902) destacó a Sorolla como la principal figura artística del momento, no encontró en él la voluntad de encarnar una determinada imagen de España, como si hacía Zuloaga, que «solo trata de 
conseguir el carácter español en sus figuras», retratar con sus escenas «el tipo de la raza» (Beruete, 1924).

Zuloaga incluyó a Sorolla entre los pintores españoles que seleccionó para la Bienal de Venecia de 1905. Pese a sus diferentes planteamientos pictóricos - «siempre hace la impresión de una fotografía instantánea, ampliada e iluminada» (Gómez de Caso, 2019: 89)-, reconocía por carta a su tío que una de las obras que Sorolla había presentado al Salón de ese año era la más notable del certamen ${ }^{5}$. Un año después, a raíz de la exposición que este realizó en el Salón Petit, su opinión había cambiado notablemente: «que su cerebro está completamente vacío de arte pero sí lleno de maldad; que los retratos son horribles [...]: que para él, el Arte es el aproximarse lo más posible al natural y copiarlo como un cabrón $»^{6}$ (Gómez de Caso, 2019: 139). Parte de su enfado lo originó una crítica publicada por Saint-Aubin en Heraldo de Madrid, en la que, como el propio Zuloaga afirmaba, atacaba su pintura sin nombrarle: «No lleva Sorolla la España de romances y aleluyas [...] No seguirán formando [...] la equivocada y tristísima idea que de nosotros tienen en el extranjero [...]. Sorolla demostrará con retratos maravillosos que no es hoy España un país de pandereta» (1906: 1). Que ambos artistas expusieran de forma consecutiva en Nueva York en 1909, y que Sorolla obtuviera mayor reconocimiento, no hizo sino incrementar la rivalidad que sentía Zuloaga. La prensa aprovechó la ocasión para confrontar la obra de ambos. Brinton afirmó que la crítica española encontraba en ellos «un irreconciliable dualismo de tendencias», pese a que, en su opinión, ambos se completaban en sus esfuerzos por ofrecer «un magnífico panorama de la vida, de la escena y del carácter nacionales» (1909: 556). Pero la identificación definitiva de la obra de cada uno con una forma opuesta de entender España la realizaría Unamuno en 1912:

Lo austero y grave, lo católico de España, [...] halla su expresión en los cuadros de Zuloaga no solo por la elección de asuntos [...], sino por la manera sobria, fuerte y austera de ejecutarlos [...]. Y la otra España, la España que podríamos llamar pagana $\mathrm{y}$ tal vez en cierto sentido progresista, la que quiere vivir y no pensar en la muerte, esta encuentra su otro pintor en Sorolla (1958: 566).

Para entonces, Sorolla estaba plenamente inmerso en la realización de su Visión de España para The Hispanic Society of America, adentrándose en una estética más propia del regionalismo que facilitaba la confrontación de su obra con la de Zuloaga. Pese a todo, insistía en afirmar su compromiso con la realidad y su alejamiento de cualquier simbolismo:

Quiero fijar, conforme a la verdad, claramente, sin simbolismos ni literaturas, la psicología de cada región; quiero dar, siempre dentro del verismo de mi escuela, una representación de España; no buscando filosofías, sino lo pintoresco de cada región. Aunque tratándose de mí no sea necesario decirlo, quiero que conste que estoy muy lejos de la españolada (citado en Pantorba, 1953: 93).

\section{El regionalismo pictórico: simbolismo e identidad}

Si hacia 1900 las escenas valencianas de Sorolla o sus discípulos no parecían encarnar una idea de nación, tampoco lo hacían las andaluzas de Gonzalo Bilbao, ni cualquier otro de los tipos regionales retratados por tantos pintores costumbristas en activo. Fue necesaria la concreción y difusión de la retórica de Zuloaga y de los lenguajes finiseculares para que se impusiera de forma clara esa identificación entre el tipo, la costumbre, el paisaje y la nación. Un proceso que se concretó entre 1905 y 1907, aún sin 
consenso en torno a la figura de Zuloaga, en una nueva generación de autores como Aurelio Arteta, Alberto Arrúe, Ramón de Zubiaurre, Fernando Álvarez de Sotomayor, Eugenio Hermoso, Julio Romero de Torres, Nicanor Piñole, o Marín Bagüés. Artistas ajenos al centro madrileño eran capaces de articular una nueva imagen de la nación a través de sus regiones.

En la Exposición Nacional de 1904, Labiada señalaba tres «peligros» para los pintores españoles: «el sorollismo, el zuluaguismo (sic) y el rusiñolismo» (1904: 182), señalando el primero como el más extendido. Pronto se incrementarían los seguidores del segundo y se reduciría la influencia del tercero. A partir de 1906 se vivió también una paulatina aceptación del simbolismo -también denominado idealismo o primitivismo -, cuyo apogeo situó Calvo Serraller (1998: 210) en la década siguiente. Sería clave en su difusión el Nuevo Café de Levante y los contertulios allí reunidos en torno a ValleInclán, muchos de ellos partícipes de la estética regionalista.

En 1914, García Maroto situaba a Sorolla como el primero en derrotar «la antigua y nefasta manera» (s.d.: 66). De acuerdo con una visión evolutiva del arte, entendía que a este le siguió Zuloaga, «que buscó el pulso a España en la hora de la derrota, y encontrando el mal, lo marcó ante nuestros ojos, y al hacerlo, pedía por nuestra salvación y mostraba el remedio» (72). José Francés confirmaba poco después ese mismo planteamiento al señalar a Sorolla como el «precursor» y al «sorollismo» como una vía que pronto se vio insuficiente. Zuloaga, con su arte pensado para la exportación, actuó entonces como "guía pictórico» (1916: 105-106). Y se impuso así el españolismo. Su propuesta para el futuro consistía en acabar con la separación radical entre realismo e idealismo.

El naturalismo y su tendencia a la captación del instante podía caer en la trivialización de lo local a través de un uso excesivo de la anécdota. Cuando se quiso que la pintura encarnara determinadas esencias regionales y/o nacionales, fue necesario articular símbolos acordes con la retórica identitaria, figuras que tuvieron que trascender y convertirse en arquetipos. Contenedores de valores de difícil concreción y sujetas a interpretaciones diversas. Se imponía lo intemporal, lo antinatural, lo ritual, la costumbre convertida en mito. Fue lo que Manuel Abril describió en 1935 como el paso De la naturaleza al espíritu:

Lo que comenzó en costumbrismo ha ido adquiriendo caracteres de apoteosis; lo que comenzó por ser un «trozo del natural» se va convirtiendo en «un trozo de retablo»: hieratismo, liturgia, espiritualización, divinización o epifanía del influjo misterioso y creador que adopta, al encarnar, modalidades regionales o se va convirtiendo en fantasía de apoteosis popular.

La región adquiere de ese modo carácter trascendental porque se la va concibiendo en función de una sabia interior que la informa (1935: 52).

Zuloaga había abierto ese camino y no sin dificultades. La imagen de «lo español» que ofrecía con su pintura fue tildada de falsa, negativa y extranjerizante, pero el problema no residía en los asuntos elegidos sino en la forma de retratarlos. Era su modernidad plástica la que desafiaba ciertas convenciones. Una modernidad que queriendo ser profundamente española procedía de fuentes francesas. Fue su reinterpretación de los avances del naturalismo a partir de las premisas del simbolismo la que logró dar una respuesta satisfactoria al debate identitario. Así, al menos, lo terminó por entender la crítica, además de la nueva generación de pintores que proliferó por las diferentes regiones españolas. 


\section{BIBLIOGRAFÍA}

ABRIL Manuel (1935), De la naturaleza al espíritu. Ensayo crítico de pintura contemporánea desde Sorolla a Picasso, Madrid: Espasa-Calpe.

ALCÁNTARA Francisco (1901), «Exposición de Bellas Artes de 1901», Nuestro Tiempo (5), mayo, Madrid, 829-837.

ALCÁNTARA Francisco (1910), «Ignacio Zuloaga», El Imparcial, 19 de marzo, Madrid, 2.

ALEXANDRE Arsène (1903), «La Société Nationale des Beaux-Arts», Le Figaro, 15 de abril, París, 3.

«De arte. Una carta de Zuloaga» (1904), Heraldo de Aragón, 12 de diciembre, Zaragoza, 1.

AzoRín (1910), «La España de un pintor», ABC, 7 de abril, Madrid, 5-6.

Azorín (1912), «La pintura de Zuloaga», El Pueblo Vasco, 21 de febrero, San Sebastián, 1.

BALSA DE LA VEGA Rafael (1892), Los bucólicos (La pintura de costumbres rurales en España), Barcelona: Tipo-litografía de Espasa y Compañía.

BÉNÉDITE Léonce (1900), «L'exposition Décennale. La peinture étrangère», Gazette des Beaux-Arts (552), 1 de diciembre, París, 577-592.

BÉNÉDITE Léonce (1904), «Beaux-Arts», Rapports du Jury International, París: Imprimerie Nationale, 123-674.

BÉNÉDITE Léonce (1912), Ignacio Zuloaga, París: Librairie Artistique Internationale.

BERUETE Y MORET Aureliano de (1924), Historia de la pintura del siglo XIX (manuscrito original de 1902), Madrid: Ateneo.

BLAsco Ricardo (1901), «Pintores españoles», La Correspondencia de España, 25 de abril, Madrid, 1.

BLASCO IBÁÑEZ Vicente (1900), «El gran Sorolla», Heraldo de Madrid, 10 de junio, Madrid, 1.

BonAFOUX Luis (1901), «iQué lo ahorquen!», Heraldo de Madrid, 29 de abril, Madrid.

BOUYER Raymond (1898), «L'art et la beauté aux Salons de 1898», L'Artiste. Revue de L'Art

Contemporain (A68, TI), enero-marzo, París, 97-192.

BozAl Leyre \& JimÉnEz Pablo (2017), «Zuloaga en el París de la Belle Époque», L. Bozal \& P. Jiménez (dir.), Zuloaga en el París de la Belle Époque, 1889-1914, Madrid: Fundación Mapfre, 10-25.

BRINTON Christian (1909), «Sorolla y Zuloaga», Por Esos Mundos (173), Madrid, 555-561.

C. (1900), «La exposición de París», La Época, 16 de enero, Madrid, 1.

CABello y LAPIEDRA Luis M. (1897), «Desde Madrid. Exposición de Bellas Artes IV», Arquitectura y Construcción (11), 8 de agosto, Barcelona, 161-167.

CALVo SerRaller Francisco (1997), «El simbolismo y su influencia en la pintura española del fin de siglo», Pintura simbolista en España (1890-1930), Madrid: Fundación Mapfre, 17-59.

CALVo SerRaller Francisco (1998), Paisajes de luz y muerte. La pintura española del 98, Barcelona: Tusquets.

CARRIón Julio L. (1900), «Movimiento artístico», Iris (81), 24 de noviembre, Barcelona, s.p. 
CHARLES-BRUN Jean (1918), El regionalismo (obra original publicada por Bloud \& Cie. en 1911), Madrid: Francisco Beltrán.

CHECA Ulpiano (1900), «Los pintores españoles en París», Heraldo de Madrid, 24 de mayo, Madrid. Cossío Manuel B. (1985), Aproximación al arte español (estudio y notas de A. M. de Cossío), Madrid: Akal (manuscrito original de 1884).

ENCINA Juan de la (1919), La trama del arte vasco, Bilbao: Editorial vasca.

ENSEÑAT Juan B. (1900), «Crónicas de la exposición de París», La Ilustración Artística (970), 30 de julio, Barcelona, 490.

«La exposición de París» (1900), La Época, 1 de mayo, Madrid, 2.

Facos Michelle (2009), Symbolist Art in Context, Berkeley: University of California Press.

FRANCÉs José (1904), «De la exposición», Nuevo Mundo (542), 26 de mayo, Madrid, s.p.

FRANCÉs José (1916), El año artístico 1915, Madrid: Mundo Latino, 104-107.

FRANTZ Henri (1903), «A Modern Spanish Painter: Ignacio Zuloaga», The Studio (125), Londres, 158-169.

GANIVET Ángel (1897), Idearium español, Granada: por Tip. Lit. Vda. E Hijos de Sabatel.

GARCíA MAROTO Gabriel (s.d.), Teoría de las artes nobles. Elementos de filosofía e historia del arte español, La Solana: R. de la $O$.

GIL M. (1909), «En el estudio de Zuloaga», Five Essays on the Art of Ignacio Zuloaga, Nueva York: The Hispanic Society of America, 83-115.

GómEZ DE CASo Mariano (2019), Correspondencia de Ignacio Zuloaga con su tío Daniel: <http:// www.museoignaciozuloaga.com/es/bibliografia/item/309-correspondencia-de-i-z-con-suti\%CC\%81o-d-z-actualizada-2019.html> (23 marzo 2019).

HIRSCH Sharon (1994), «Hodler as Genevois, Hodler as Swiss», Ferdinand Hodler. Views \& Visions, Zurich: Swiss Institute for Art Research, 66-107.

HUTCHINSON John (2013), «Cultural Nationalism», J. Breuilly (dir.), The Oxford Handbook of the History of Nationalism, Oxford: Oxford University Press, 75-94.

«Ignacio Zuloaga» (1900), Pèl \& Ploma, 27 de enero, Barcelona, s.p.

JIMÉNEZ Luis (1900), «Arte y artistas», Heraldo de Madrid, 16 de mayo, Madrid.

LABIADA Leonardo (1904), «La Exposición de Bellas Artes», La Lectura (41), mayo, 182-186.

LEEMAN Fred (2013), Émile Bernard (1868-1941), París: Wildenstein Institute.

LEEMAN Fred (2014), «Symbolisme et religion. Émile Bernard et le sens de l'art», Émile Bernard (1868-1941), París: Flammarion, 10-21.

LERTXUNDI Mikel (2019), «Zuloaga antes de Zuloaga (1870-1898)», Zuloaga (1870-1945), Bilbao: Museo de Bellas Artes de Bilbao, 15-51.

LERTXUNDI Mikel \& Novo Javier (2019), «Zuloaga (1898-1924)», Zuloaga (1870-1945), Bilbao: Museo de Bellas Artes de Bilbao, 53-105.

LomBA Concha (2017), «El París que recibió a Zuloaga», L. Bozal \& P. Jiménez (dir.), Zuloaga en el París de la Belle Epoque, 1889-1914, Madrid: Fundación Mapfre, 28-39. 
MACíAs PiCAVEA Ricardo (1899), El problema nacional, Madrid: Victoriano Suárez.

MAEZTu Ramiro de (1903), «La nueva pintura española en París y en Bilbao», La Lectura (A3T2), Madrid, 14-34.

MAEZTU Ramiro de (1910), «Cosas y hombres», Heraldo de Madrid, 9 de noviembre, Madrid, 1.

MANIFIESTO PARA LA SOLIDARIDAD GALLEGA (1907), La Coruña: F. García Ibarra.

MiLHou Mayi (1981), Ignacio Zuloaga et la France, Saint-Loubès: Graphilux.

MORICE Charles (1895), «Expositions. Chez le Barc de Boutteville. Ignacio Zuloaga», L'Idée Libre (4), año IV, París, 179-180.

NúÑEZ Xosé M. (2006), «Provincia, región y nación en la España contemporánea: una (re)interpretación global en perspectiva comparada», C. Forcadell \& M. C. Romeo (dir.), Provincia y nación: los territorios del liberalismo, Zaragoza: Institución Fernando el Católico, 297-312.

OpIsso Alfredo (1896), «Exposición de Bellas Artes de Barcelona», La Ilustración Ibérica (704), 27 de junio, Barcelona, 410-414.

ORTEGA Y GASSET José (1910a), «¿Una exposición Zuloaga?», El Imparcial, 29 de abril, Madrid, 1.

ORTEGA Y GASSET José (1910b), «Adán en el paraíso», El Imparcial, 4 de mayo, Madrid, 1.

ORTEGA Y GASSET José (1911), «La estética del “enano Gregorio el Botero” II», El Imparcial, 10 de noviembre, Madrid, 3.

PANTORBA Bernardino de (1953), La vida y la obra de Joaquín Sorolla, Madrid: Mayfe.

PÉREZ JoRbA Joan (1903), «Crónicas de arte y de sociología», La Revista Blanca (119), 1 de junio, Madrid, 730-734.

PLESSIER Ghislaine (1995), Ignacio Zuloaga et ses amis français, París: L’Harmattan.

PORTÚs Javier (2012), El concepto de pintura española. Historia de un problema, Madrid: Verbum.

Pujol Juan (1912), «La estética de Zuloaga explicada por él mismo», El Pueblo Vasco, 22 de febrero, San Sebastián, 1.

«Quadro den Zuloaga» (1900), Pèl \& Ploma, 24 de marzo, Barcelona, s.p.

Roviralta Josep María (1898), «Arte nuevo. La regeneración estética en España», Luz (6), tercera semana de noviembre, Barcelona, 62-63.

SAINT-AuBIN Alejandro (1899), «Exposición de Bellas Artes», Heraldo de Madrid, 11 de mayo, Madrid, 1.

SAINT-Aubin Alejandro (1906), «Sorolla en París», Heraldo de Madrid, 12 de junio, Madrid, 1.

STEVENS Maryanne (2000), «The Exposition Universelle: ‘This vast competition of effort, realization and victories'», 1900, Art at the Crossroads, Nueva York: Harry N. Abrams, Inc., 55-71. STORM Eric (2010), The Culture of Regionalism, Manchester: Manchester University Press. TAINE Hippolyte (1960), Filosofía del arte (Fernado Herce, trad.), Barcelona: Iberia (obra original editada por Germer Baillière entre 1865 y 1882).

THIESSE Anne-Marie (1999), La création des identités nationales : Europe XVIII ${ }^{e}-X X^{e}$ siècle, Paris: Seuil. THOMson Richard (2012), Art of the Actual. Naturalism and Style in Early Third Republic France, 1880-1900, New Haven: Yale University Press. 
UNAMUNo Miguel de (1895), «En torno al casticismo. La tradición eterna», La España Moderna

(A7T74), febrero, 17-40.

UnAMUNo Miguel de (1958), Obras completas. Tomo XI. Meditaciones y otros escritos, Madrid: Afrodisio Aguado.

VALENZUEla la RoSA José (1903), «Arte Moderno. El caso “Zuloaga”, Revista de Aragón (4), noviembre, Zaragoza, 259-263.

VIAN Marie-Paule (2017), «Émile Bernard e Ignacio Zuloaga: una amistad inquebrantable», L. Bozal \& P. Jiménez (dir.), Zuloaga en el París de la Belle Époque, 1889-1914, Madrid: Fundación Mapfre, 252-283.

WILLIAMS Leonard (1904), «Joaquín Sorolla y la pintura española actual», La Lectura (41), mayo, 121-125.

YBARRA Casilda (2017), «Selección de textos», L. Bozal \& P. Jiménez (dir.), Zuloaga en el París de la Belle Époque, 1889-1914, Madrid: Fundación Mapfre, 252-283.

\section{NOTAS}

1. Carta de Ignacio Zuloaga a Isaac Albéniz, Segovia, 20 de diciembre de 1899. Arxiu del Museu de la Música de Barcelona. ES AMDMB 3-408-04-01-10.323.

2. De acuerdo con la exhaustiva investigación realizada por Mikel Lertxundi y Javier Novo no hay constancia documental y resultan poco probables los dos viajes anteriores a Sevilla que se han venido citando.

3. Fragmento traducido del texto original en francés recogido en: Milhou, 1981: 112.

4. Cabría citar, entre otros, los trabajos de Calvo Serraller (1997), Bozal y Jiménez (2017) o Lomba (2017).

5. Carta de Ignacio Zuloaga a su tío Daniel Zuloaga fechada el 1 de mayo de 1905.

6. Carta de Ignacio Zuloaga a su tío Daniel Zuloaga fechada el 28 de junio de 1906.

\section{RESÚMENES}

A partir de su contacto directo con el simbolismo internacional, la pintura de Ignacio Zuloaga supo trascender los estrictos límites del naturalismo costumbrista ofreciendo una solución moderna al problema de la representación de las esencias de la nación española. Pese a la complicada recepción que tuvo en España la imagen del país que difundía, condicionó el rumbo de la pintura española a partir de 1900. Esta, por más que buscara encarnar lo español, tenía su origen en la capital francesa.

À partir de sa connaissance du symbolisme international, la peinture d'Ignacio Zuloaga a su dépasser les limites strictes du naturalisme, offrant une solution moderne au problème de la représentation de l'essence de la nation espagnole. Malgré la réception complexe qui fut réservée en Espagne à l'image qu'il diffusait de ce pays, son influence fut déterminante dans la direction 
que prit la peinture espagnole à partir de 1900. Même si elle s'efforçait d'incarner l'hispanité, ses origines se trouvaient dans la capitale française.

From his direct contact with international symbolism, Ignacio Zuloaga's painting knew how to transcend the strict limits of naturalism by offering a modern solution to the problem of representing the essence of the Spanish nation. Despite the complicated reception that the image of the country it spread had in Spain, it conditioned the course of Spanish painting from 1900 onwards. This one, although it sought to embody Spain, had its origin in the French capital.

\section{ÍNDICE}

Palabras claves: Zuloaga, identidad nacional, simbolismo, naturalismo

Mots-clés: Zuloaga, identité nationale, symbolisme

Keywords: Zuloaga, national identity, symbolism, naturalism

\section{AUTOR \\ ALBERTO CASTÁN CHOCARRO}

Universidad de Zaragoza

alcastan@unizar.es 